\title{
Shift in Global Tantalum Mine Production, 2000-2014
}

Tantalum has a unique set of properties that make it useful in a number of diverse applications. The ability of the metal to store and release electrical energy makes it ideally suited for use in certain types of capacitors that are widely used in modern electronics. Approximately 60 percent of global tantalum consumption is in the electronics industry (Papp, 2015). The ductility and corrosion resistance of the metal lends itself to application in the chemical processing industry, and its high melting point and high strength retention at elevated temperatures make it an important component of super alloys used in aircraft engines (Global Advanced Metals Pty Ltd, 2010).

As a major industrialized nation, the United States is a leading consumer of tantalum and tantalum-containing products. Domestic deposits typically are of low grade, and no tantalum has been recovered from mining activities in the United States since 1959 (Wessel, 1961). Consequently, the United States is nearly completely reliant on imports to meet its domestic consumption of tantalum for economic and national security needs. The recovery of tantalum from mine production is economically viable in only a few countries.

Although developed countries dominated tantalum mine production in the early 2000 s, production today is dominated by countries in the Great Lakes Region of Africa (figs. 1 and 2). There is concern that the sales of minerals, including columbite-tantalite or "coltan," a mineral from which tantalum is derived, have helped finance rebel groups accused of violating human rights as part of the continuing armed conflict in the Democratic Republic of the Congo (DRC) and neighboring countries. These accusations have prompted the passage of legislation in the United States to curb the procurement of these mineral commodities, referred to as "conflict minerals," from the DRC. Specifically, section 1502 of the 2010 Dodd-Frank Wall Street Reform and Consumer Protection Act (Public Law 111-203, 124 Stat. 2213-2218) requires companies that source tantalum, tin, tungsten, and gold (3TG) to perform due diligence on their supply chains to determine if the materials they use originate from the DRC or adjoining countries (defined as sharing a border with the DRC) (U.S. Securities and Exchange Commission, 2012; Chasan, 2015; U.S. Department of State, 2015).

The DRC, Rwanda, and surrounding countries are not globally significant sources of tin, tungsten, or gold, accounting for only about 2 percent of the mined world supply for each of these elements. The region has, however, evolved to become the world's largest producer of mined tantalum.

A further complication of the production of tantalum stems from the opacity of the tantalum market. Unlike most base and precious metals, tantalum concentrates are not publicly traded through commodities exchanges but are bought and sold through networks of dealers and on contract between producers and consumers, some of whom may not provide accurate statistical data concerning the amounts, origins, and destination of the concentrates (Browning, 2015; Tantalum-Niobium International Study Center [TIC], 2015). Some price data can be found in trade journals or in other publications; however, there are no recognized official

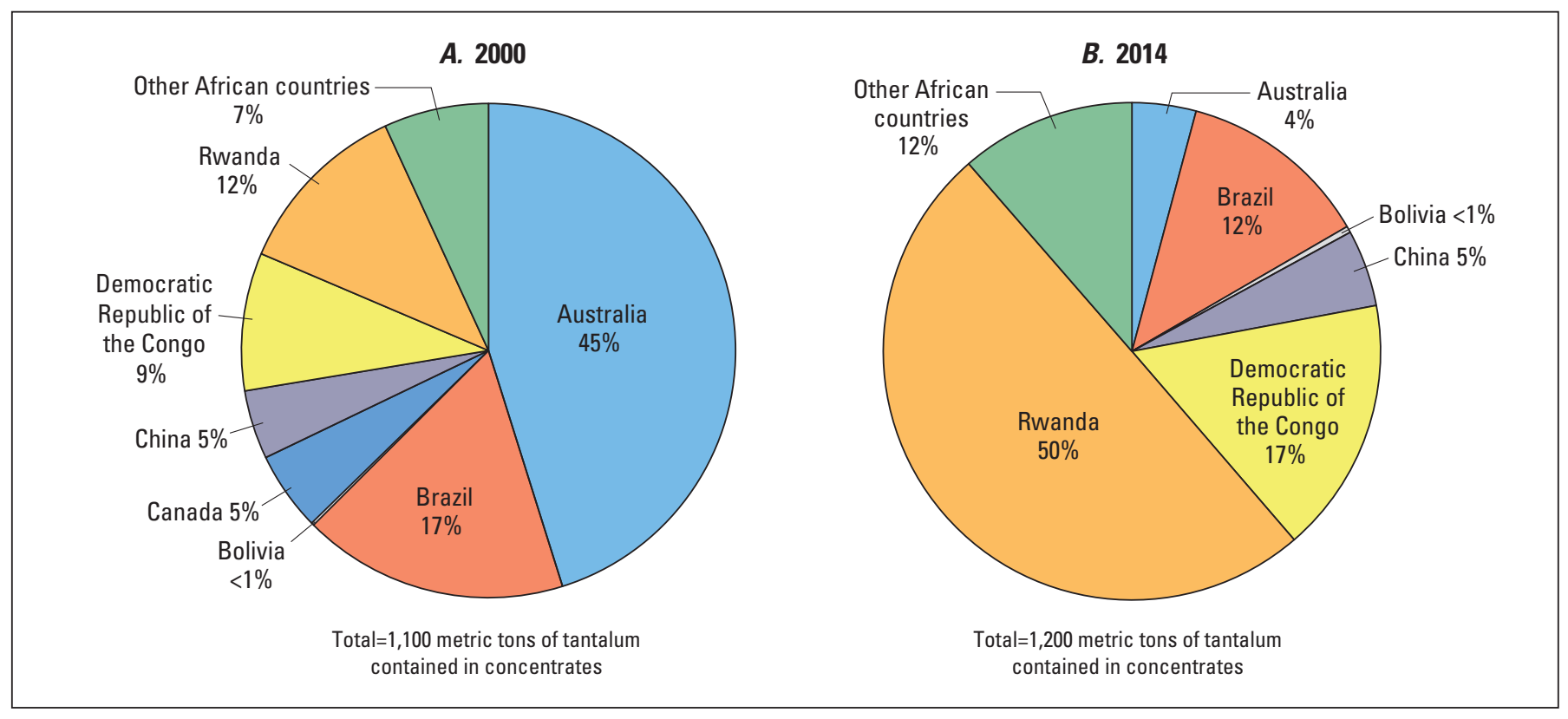

Figure 1. Mine production of tantalum contained in concentrates, by country of origin, for $2000(A)$ and $2014(B)$. 
set exchange prices for either concentrate or tantalum metal. Because price is determined by negotiation between buyer and seller (TIC, 2015), published prices for concentrate are probably not representative of global prices paid for concentrate. The development of a mine-to-market supply-chain analysis is complicated and difficult because many of the industry participants that produce, trade, and consume tantalum do not publish statistical information, contracts are long term between miners and buyers, and much of the industry is vertically integrated.

As a result of these and other considerations, tantalum is considered by many to be a "critical" commodity (National Research Council, 2007; Erdmann and Graedel, 2011; Meinert, 2014; Geoscience Australia, 2015). This fact sheet identifies and addresses the major geographic shifts in the sources of mine production of tantalum which have occurred over the past 15 years, some of the factors that drove these shifts, and some of the related consequences.

One of the activities of the U.S. Geological Survey National Minerals Information Center (USGS-NMIC) is to analyze global supply chains and characterize major components of mineral and material flows from ore extraction through processing to first tier products. These analyses support the core mission of the USGS-NMIC as the Federal entity responsible for the collection, analysis, and dissemination of objective, unbiased, factual information on minerals essential to the U.S. economy and national security.

\section{Global Tantalum Mine Production}

The estimated annual mine production of tantalum contained in tantalum and tin concentrates for 2000-2014 is shown in figure 2 for 15 countries. The USGS-NMIC analysis does not address the amount of tantalum ultimately recovered from these concentrates, which may be considerably less because of the losses experienced during processing to produce marketable products.

Mine production data are published in USGS Minerals Yearbook and Mineral Commodity Summaries publications available at http://minerals.usgs.gov/ minerals/. In some instances, data have been revised to reflect the current state of knowledge. Data limitations prevent estimating the amounts of potentially recoverable tantalum contained in tantalum and tin concentrates that are produced annually in a number of countries including Malaysia, Russia, and Thailand. Most of this production is a byproduct of the mining and smelting of cassiterite, an ore mineral for tin, and, to a much lesser extent, wolframite and scheelite, ore minerals for tungsten. Tantalum contained in slags from past smelting activities in Australia, Brazil, Portugal, and several Asian countries also is excluded from the estimates because of data limitations. The level of information required to develop estimates of undocumented tantalum production that originated in conflict and some nonconflict areas in Africa, South America, and some other locations was not available.

Several major events during the period 2000 to 2014 influenced mine production (fig. 2). These events included (1) the effects of rapid increases in tantalum demand and consumption that resulted in higher prices just prior to the year 2000 during the "dot-com boom," followed by the bursting of the "dot-com bubble" in 2000 that lingered into 2002; (2) the global recession in 2008-2009, which decreased demand for most mineral commodities; (3) regional armed conflicts in the Great Lakes Region of Africa, primarily the DRC and Rwanda, through much of the period analyzed; and (4) proposed and enacted legislative action in Europe and the United States in response to issues related to conflict minerals, such as implementation of the Dodd-Frank Act in 2010.

The data indicate that the total amount of tantalum contained in tantalum and tin concentrates in the countries studied averaged about 1,300 metric tons per year ( $\mathrm{t} / \mathrm{yr}$ ) (expressed as tantalum contained in concentrate) for the period 2000 to 2014. Tantalum derived from mining, the focus of this fact sheet, is a component of total supply, which also includes secondary production (recycling), and contributions from releases of inventories.

In 2000, a total of approximately 1,100 metric tons $(t)$ of tantalum in concentrate was produced among the countries studied. Australia was by far the dominant global producer of mined tantalum in concentrates with a 45 percent share of global production, mostly from the Greenbushes and Wodgina Mines. Other leading producers in that year were Brazil (17 percent), Rwanda (12 percent), and the DRC (9 percent) (figs. 1 $A, 2$ ). Beginning in 2006, the Greenbushes Mine began to reduce production, and, by 2009 , the Greenbushes and Wodgina Mines were placed on care and maintenance, ending Australia's position as the world's leading producer of tantalum in concentrate.

The estimated annual production of tantalum contained in tantalum and tin concentrates in the DRC and Rwanda was relatively modest for the period 2000 through 2006, averaging $101 \mathrm{t}$ and $73 \mathrm{t}$, respectively. Combined, the contribution of the two countries to tantalum-in-concentrate production among the countries studied averaged less than 15 percent during the 7-year period. In 2007, however, reported production in the DRC increased to $320 \mathrm{t}$ of tantalum in concentrate, nearly three times the average of the previous years, and mine production in Rwanda increased to $170 \mathrm{t}$ of tantalum in concentrate (fig. 2). The combined production from the 2 countries, which share a common border, represented nearly 35 percent of the total estimated mine production from the 15 countries studied. The increase in mine production from the two countries compensated to a large degree for the loss of production that resulted from the suspension of the higher-cost Australian mining operations and from the termination of releases of tantalum materials from the U.S. National Defense Stockpile.

The increase in production in the DRC and Rwanda and the decline in production in Australia were already underway prior to the global economic downturn in 2008-2009 and the drop in tantalum prices. This was a time of reduced demand for electronics and a drop in the price of tantalum. The actions on the part of the Australian mining companies were reportedly taken in response to a combination of the comparatively high costs associated with hard rock mining, the bankruptcy of the owner/operators of the Greenbushes and Wodgina Mines, and an increasing amount of lower-priced tantalum concentrates entering the supply chain from central Africa (Schwela, 2007; Global Advanced Metals Pty Ltd, 2011a, b; Taylor, 2011; Tse, 2012; Cann, 2014). 


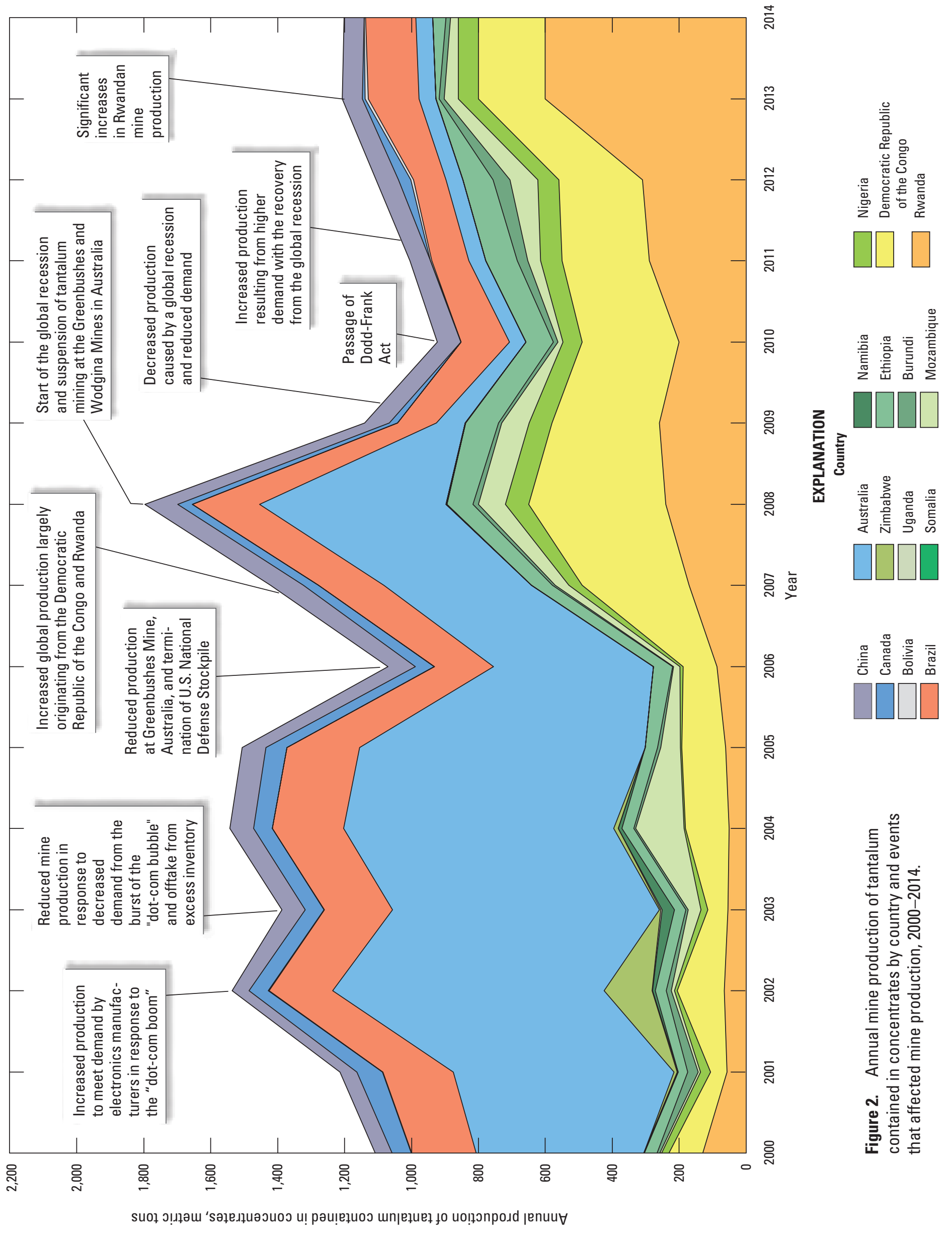


Australian and Brazilian mines, the dominant producers from 2000 through 2008, were considered low risk for supply disruptions. Although these countries had modern mining operations and transparent commerce characteristics, the Australian hard rock mines had relatively high operating costs. In contrast, concentrates supplied from Africa were mostly sourced from small, labor intensive, and relatively unsophisticated artisanal mines, producing at lower costs. Brazil was able to maintain a position as one of the world's major producers because most of the country's concentrate was derived from relatively low-cost unconsolidated placer deposits. African production increased, and the price for tantalum dropped because of decreased global demand during the global recession. Australian operations decreased or suspended production (Schwela, 2010; Millman, 2014) and, by 2007, the country had lost a significant share of global supply to the DRC and Rwanda (fig. 2).

In 2009, the geographic distribution of world tantalum mine production shifted dramatically from Australia and Brazil, with a combined global share of 18 percent, to the DRC and Rwanda, with a combined share of 51 percent ( 28 percent and 23 percent, respectively). Although still retaining a major share of global production, the DRC had begun to decline in production from the high of $410 \mathrm{t}$ achieved in 2008 (fig. 2). Although Brazil retained its position as the third largest producer of tantalum in concentrate, the leading Australian mines were not reactivated to previous production levels as the recovery from the global recession continued. Instead, most of the world's demand for tantalum in concentrate was met by the DRC and Rwanda (fig. 2).

Over the past decade, reports published by the United Nations Group of Experts (UN GoE) on the DRC and other nongovernmental organizations identified foreign and domestic armed groups that reportedly took control of many artisanal mining operations and intercepted trade to profit from the production of $3 \mathrm{TG}$ minerals. The revenues collected by these armed groups reportedly continued to perpetuate civil unrest in some areas in the DRC (Bermúdez-Lugo, 2014). Ores and concentrates that originated in the DRC may have been transported illegally to some bordering countries and, when sold, reported as being produced from the bordering countries (de Ville, 2009; Bleischwitz and others, 2012; Polinares, 2013; Bafilemba and others, 2014).

In 2013, Rwanda became the world's leading producer of tantalum contained in tantalum and tin concentrates with an estimated $600 \mathrm{t}$, which is nearly 50 percent of the total estimated production from the countries studied. This was a major increase from the estimated $310 \mathrm{t}$ of tantalum in concentrate produced in Rwanda in 2012 when it represented about 28 percent of the production among the countries studied. In December 2013, the Rwandan Government disclosed that they had "dramatically" increased their tantalum concentrate exports and had become the world's largest exporter, mostly to China, which has been a major importer of concentrates from Rwanda (Bleischwitz and others, 2012; Browning, 2015). This noteworthy increase in production may be attributed to the Government privatization of its mining operations and opening new concessions to investors and artisanal cooperatives (Yager, 2014).

In 2014, the combined production of tantalum contained in concentrate in the DRC and Rwanda represented nearly 70 percent of global production among the countries studied. World mine production further established these African countries as the world's major tantalum-in-concentrate producers (figs. 1B,2).

Reports indicate that the implementation of the Dodd-Frank Act resulted in an increase in tantalum concentrate production in parts of the DRC that were determined to be conflict free (Bafilemba and others, 2014). In 2013 and 2014, the estimates of annual mine production in the DRC decreased to about $200 \mathrm{t}$ of tantalum in concentrate but continued to represent about 17 percent of estimated mine production among the countries studied (figs. $1 B, 2$ ). There have been claims over the years by nongovernmental organizations, United Nations observers, and others that at least some portion of Rwanda's reported production for the period analyzed originated from concentrates smuggled across the border from conflict areas in North Kivu and South Kivu in the DRC and was exported through Rwanda's domestic tagging system as a nonconflict source (de Ville, 2009; Bleischwitz and others, 2012; Polinares, 2013; Bafilemba and others, 2014).

It has been reported that after 2011 western companies did not purchase tantalum concentrate from the Great Lakes Region unless it was determined to be conflict free to avoid contaminating their supply chain and to conform to legislation (Bafilemba and others, 2014). However, in 2014, nearly 70 percent of the estimated amount of tantalum contained in concentrate among the countries included in this study originated from the DRC and Rwanda. The percentage share represents a major change from the year 2000, when about 20 percent of the production of tantalum in concentrate originated from the DRC and Rwanda (figs. $1 A, B ; 2$ ). If producers and traders were unable to prove that the tantalum concentrate was conflict free, they could allegedly sell to Chinese or other buyers at an approximately 30 to 60 percent discount (de Ville, 2009; Bleischwitz and others, 2012; Polinares, 2013; Bafilemba and others, 2014).

A significant increase in tantalumin-concentrate production from about 2007 through 2014 was reported for Rwanda; this coincides with the general decrease in estimated production from the DRC during the same period. On the basis of preliminary data, the 2014 production levels in the two countries were estimated to have been similar to 2013 production levels. The inherent risks associated with conflict in the Great Lakes Region may present a potential risk for short-term disruption of tantalum in concentrate to the global tantalum supply (Polinares, 2013; Green, 2014; Mining Journal, 2015).

Brazil has been a relatively steady and significant producer of tantalum concentrate for over the entire period analyzed. Purchasing tantalum concentrate from Brazil may be attractive to some buyers because its origin is simpler to certify as a nonconflict mineral. Brazil may also be in a position to expand production if supply from the Great Lakes Region were to be disrupted. Given favorable economics and other factors, Australian operations on careand-maintenance status could be reactivated to mitigate, in large measure, a loss of supply from the Great Lakes Region. 
The Bernic Lake operation in Canada, although historically a source of minor production of tantalum concentrate, was the only North American tantalum mine that has operated within the last 50 years. Although the tantalum ore processing portion of the facility was placed on care-and-maintenance status in 2013, the site's proximity to the United States strengthens its strategic value as a potentially important source of tantalum concentrate.

In 2014, the total production of nearly 1,200 t of mined tantalum in concentrate from 15 countries studied was substantially lower than what was estimated just prior to the global recession in 2008 when nearly $1,800 \mathrm{t}$ was produced. Possible reasons for the reduction include (1) global tantalum consumption had still not recovered to the previous levels of a more robust economy; (2) improvement in the efficient use of the metal or increased substitution; (3) drawdown of producer inventories;
(4) increased usage of secondary (recycled) material; and (5) unaccounted tantalum production entering the supply chain, some of which may originate from conflict-affected sources. The USGS-NMIC has no statistical information with regard to the undocumented amounts and origins of conflict minerals in the global supply chain.

\section{Summary}

The United States is highly dependent on imports of tantalum concentrate, refined metal and its alloys, and semi- and fully manufactured products to meet its industrial and strategic requirements. Dependence on a limited number of countries for supply may increase the vulnerability of the United States to the effects of supply disruptions. Additionally, governance risk associated with the largest sources of mined tantalum production may increase the risk of supply disruptions. The amount of tantalum maintained in the U.S. National Defense Stockpile has decreased significantly over the last decade as a result of selling the material into the marketplace, thereby removing one buffer which may have served to mitigate the risks associated with supply disruptions. World tantalum mine production has undergone an important geographic shift since the start of the 21 st century when production was predominantly from Australia and Brazil. Beginning in 2007 and through 2014, the major sources of tantalum production from mines dramatically shifted to the DRC, Rwanda, and some other African countries. Consequently, over the 15 -year period studied, the world's largest sources of mine production have transitioned from countries with low governance risk, modern mechanized mining and advanced processing technologies, and transparent supply chains, to countries with higher governance risk, artisanal mineral production techniques, and far less transparent supply chains.

Top, Artisanal tantalum mining in central Africa. Bottom, Artisanal miners in central Africa washing tantalum ore to produce concentrate. Photographs provided courtesy of Richard Burt, former President of the TantalumNiobium International Study Center (T.I.C.).
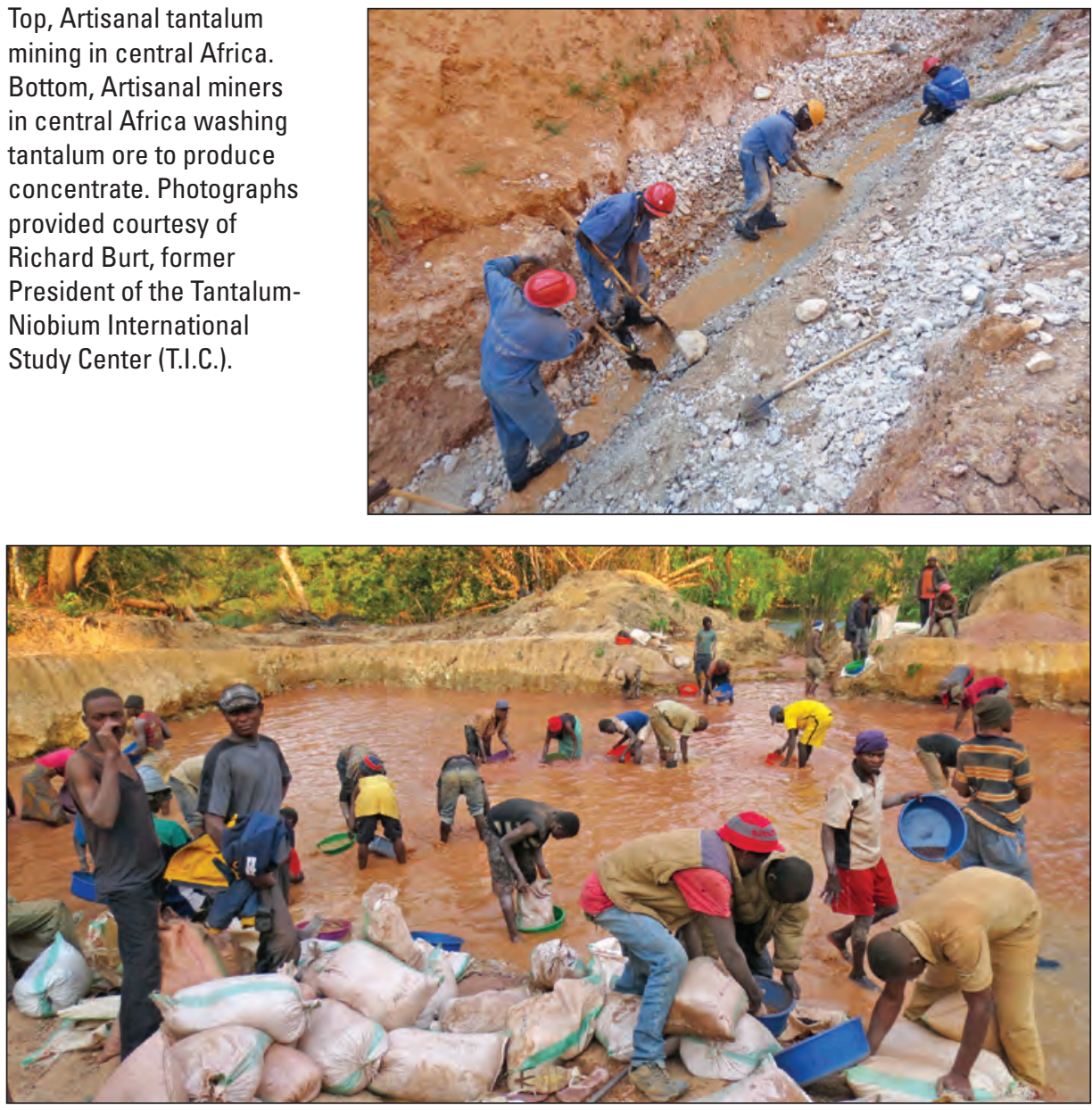


\section{References Cited}

Bafilemba, Fidel, Mueller, Timo, and Lezhnev, Sasha, 2014, Executive summary-The impact of the Dodd-Frank and conflict minerals reforms on eastern Congo's conflict: The Enough Project, 30 p., accessed May 14, 2015, at http://www.enoughproject.org/files/Enough\%20 Project $\% 20-\% 20$ The $\% 20$ Impact $\% 20$ of $\% 20$ Dodd-Frank $\% 20$ and $\% 20$ Conflict\%20Minerals\%20Reforms\%20on\%20Eastern\%20Congo's\%20 Conflict\%2010June2014.pdf.

Bermúdez-Lugo, Omayra, 2014, Conflict minerals from the Democratic Republic of the Congo - Global tungsten processing plants, A critical part of the supply chain (ver. 1.1, August 2014): U.S. Geological Survey Fact Sheet 2014-3069, 4 p., accessed May 12, 2015, at http://dx.doi.org/ $10.3133 /$ fs20143069.

Bleischwitz, Raimund, Dittrich, Monika, and Pierdicca, Chiara, 2012, Coltan from Central Africa, international trade and implications for any certification: Resources Policy, v. 37, no. 1, p. 19-29, accessed April 29, 2015, at http://www.researchgate.net/profile/Raimund_ Bleischwitz/publication/254409513_Coltan_from_Central_Africa international_trade_and_implications_for_any_certification/links/ 02e7e5182383701c86000000.pdf.

Browning, Lynnley, 2015, Where Apple gets the tantalum for your iPhone: Newsweek, February 4, 2015, accessed May 14, 2015, at http://www.newsweek.com/2015/02/13/where-apple-gets-tantalumyour-iphone-304351.html.

Cann, Chris, 2014, Clock ticking on tantalum supply: Mining Journal newsletter, January 1, 2014.

Chasan, Emily, 2015, "Conflict minerals" prove hard to trace: The Wall Street Journal, August 4, 2015, p. B4.

de Ville, Géraud, 2009, Path finder-An outline of trade flows of legally and illegally extracted mineral resources from fragile states-The case of coltan in the Kivus, DRC: Brussels, Belgium, Institute for Environmental Security (IES), Pathfinder Project, December, 7 p., accessed May 1, 2015, at http://www.envirosecurity.org/pathfinder/trade/Trade_Flows.pdf.

Erdmann, Lorenz, and Graedel, T.E., 2011, Criticality of non-fuel minerals-A review of major approaches and analyses: Environmental Science and Technology, v. 45, issue 18, p. 7620-7630.

Geoscience Australia, 2015, Critical commodities, accessed November 1, 2015, at http://www.ga.gov.au/about/what-we-do/ projects/minerals/current/critical-commodites.

Global Advanced Metals Pty Ltd, 2010, Applications, accessed July 7, 2015, at http://www.globaladvancedmetals.com/tantalum/applications.aspx.

Global Advanced Metals Pty Ltd, 2011a, Sources, accessed May 13, 2015, at http://www.globaladvancedmetals.com/tantalum/sources.aspx.

Global Advanced Metals Pty Ltd, 2011b, World's largest tantalum producer resumes operations, accessed May 13, 2015, at http://www.global advancedmetals.com/news/announcements/2011/january/world $\%$ E2\%80\%99s-largest-tantalum-producer-resumes-operations.aspx.

Green, Will, 2014, Rise in global political violence challenges supply chains: Supply Management, July 5, 2014, accessed June 18, 2015, at http://www.supplymanagement.com/news/2014/rise-in-global-politicalviolence-challenges-supply-chains.

Meinert, L.D., 2014, Statement of Lawrence D. Meinert, Mineral Resources Program Coordinator, U.S. Geological Survey, U.S. Department of the Interior, before the Senate Energy and Natural Resources Committee on S. 1600, January 28, 2014, accessed on November 1, 2015, at http://www.energy.senate.gov/public/index.cfm/files/serve?File_ $\mathrm{id}=7 \mathrm{e} 32 \mathrm{ad} 7 \mathrm{~b}-0715-4851-\mathrm{aa} 5 \mathrm{~d}-\mathrm{cbc} 269120 \mathrm{df4}$.

Millman, W.A., 2014, Achieving a truly conflict free tantalum supplyGlobal conflict minerals compliance and supply chain due diligence, accessed June 15, 2015, at http://www.resolv.org/site-ppamo/files/ 2014/06/AVX-Solutions-for-Hope-Update-June-2014.pdf.
Mining Journal, 2015, DRC heads corrupt-index list: Mining Journal, June 17, 2015, accessed June 20, 2015, at http://www.mining-journal.com/ services/businessadvisory/drc-heads-corrupt-index-list/?adfesuccess $=0$.

National Research Council, 2007, Minerals, critical minerals, and the U.S. economy - Report in brief: Washington, D.C., National Academy of Sciences, accessed July 22, 2015, at http://dels.nas.edu/resources/static-assets/ materials-based-on-reports/reports-in-brief/critical_minerals_final.pdf.

Papp, J.F., 2015, Tantalum: U.S. Geological Survey Mineral Commodity Summaries 2015, p. 160-161, accessed May 5, 2015, at http://dx.doi.org/ 10.3133/70140094.

Polinares, 2013, Coltan, Congo and conflict-The Hague Centre for Strategic Studies, Report no. 21, accessed May 3, 2015, at http://www.google. $\mathrm{com} / \mathrm{url}$ ? $\mathrm{sa}=\mathrm{t} \& \mathrm{rct}=\mathrm{j} \& \mathrm{q}=\& \mathrm{esrc}=\mathrm{s} \& \mathrm{frm}=1 \&$ source $=$ web $\& \mathrm{~cd}=1 \& \mathrm{ved}=0 \mathrm{C}$ B4QFjAA\&url=http $\% 3 \mathrm{~A} \% 2 \mathrm{~F} \% 2 \mathrm{Fwww}$.hess.nl\%2Freports $\% 2 \mathrm{Fdownloa}$ $\mathrm{d} \% 2 \mathrm{~F} 125 \% 2 \mathrm{~F} 1763 \% 2 \mathrm{~F} \& \mathrm{ei}=\mathrm{j} 9 \mathrm{ZUVY}$ miG8edgwTxtoGoAQ\&usg=AFQ jCNEDzN_x9ZXTq_6HAC0S-DInXbbDpw\&bvm=bv.93112503,d.eXY.

Schwela, Ulric, 2007, Tantalum-2005/2006 (last updated July 31): Mining Journal, July 31, 2007, accessed May 5, 2015, at http://www.miningjournal.com/focus/special-reports/tantalum-20056-last-updated-july-31/.

Schwela, Ulric, 2010, The state of tantalum mining: London, United Kingdom, Mining Journal Supplement, September, 11 p.

Tantalum-Niobium International Study Center (TIC), 2015, TantalumRaw materials and processing: Tantalum-Niobium International Study Center, accessed May 26, 2015, via http://tanb.org/tantalum.

Taylor, Michael, 2011, Tantalum mining resumed at Wodgina by Australia's Global Advanced Metals: Mineweb, January 17, 2011, accessed August 27, 2015, at http://www.mineweb.com/archive/tantalum-miningresumed-at-wodinga-by-australias-global-advanced-metals/.

Tse, Pui-Kwan, 2012, The mineral industry of Australia [advance release], in Area reports-International-Asia and the Pacific: U.S. Geological Survey Minerals Yearbook 2011, v. III, p. 3.1-3.27, accessed May 12, 2015, at http://minerals.usgs.gov/minerals/pubs/country/ 2011/myb3-2011-as.pdf.

U.S. Department of State, 2015, About the Great Lakes Region, accessed July 3, 2015, at http://www.state.gov/s/greatlakes_drc/191417.htm.

U.S. Securities and Exchange Commission, 2012, SEC adopts rule for disclosing use of conflict minerals: U.S. Securities and Exchange Commission press release, August 22, 2012, accessed May 16, 2015, at http://www.sec.gov/news/press/2012/2012-163.htm.

Wessel, F.W., 1961, Columbium and tantalum, in Metals and minerals (except fuels): U.S. Bureau of Mines Minerals Yearbook 1960, v. I, p. 393-402, accessed May 12, 2015, at http://digicoll.library.wisc.edu/ cgi-bin/EcoNatRes/EcoNatRes-idx?type=article\&did=EcoNatRes. MinYB1960v1.FWessel\&id=EcoNatRes.MinYB1960v1\&isize=XL.

Yager, T.R., 2014, The minerals industry of Rwanda [advance release], in Area reports - International-Africa and the Middle East: U.S. Geological Survey Minerals Yearbook 2012, v. III, p. 35.1-35.4, accessed May 14, 2015, at http://minerals.usgs.gov/minerals/pubs/country/ 2012/myb3-2012-rw.pdf.

\section{By Donald I. Bleiwas, John F. Papp, and Thomas R. Yager}

\section{For more information, contact}

Director, National Minerals Information Center

U.S. Geological Survey

12201 Sunrise Valley Drive

988 National Center

Reston, VA 20192

ISSN 2327-6916 (print)

email: nmicrecordsmgt@usgs.gov 